\title{
Metaphor in Translation: Cognitive Perspectives on Omar Khayyam's Poetry as Rendered into ENGLISH AND KURDish
}

\author{
Rahman VEISI HASAR \\ University of Kurdistan, Iran \\ veisirahman@yahoo.com \\ Ehsan PANAHBAR \\ University of Isfahan, Iran \\ epanahbar@yahoo.com
}

\begin{abstract}
As cognitive linguistics puts it, metaphor as a cognitive phenomenon can not be relegated to linguistic expression. Therefore, in order to analyze metaphor in translation, cognitive translation hypothesis investigates its translatability and metaphorical equivalence at the conceptual level. However, in such case, the conceptual metaphor is dealt with without considering its significant relationship to the cultural models. Based on Cienki's theory (1999) postulating that the relation of the conceptual metaphor to the cultural model is similar to that of a profile to a base, and that the possibility of the interpretation and production of the conceptual metaphor depends on the cultural model, the present research reinvestigates the cognitive translation hypothesis from this perspective. The research findings reveal that translators have mostly been successful in translating metaphors dependent on shared cultural models, however, have failed to recreate metaphors dependent on non-shared cultural models. Accordingly, same mapping condition and different mapping condition are strongly dependent on the relationship between metaphors and cultural models. Thus SMC and DMC should be redefined in relation to cultural model.
\end{abstract}

Key words: metaphor; cultural model; translation; SMC; DMC; Persian; English; Kurdish

\section{Povzetek}

Kognitivno jezikoslovje metaforo dojema kot kognitivni pojav, ki ga ne gre omejiti samo na jezikoslovni izraz. Hipoteza kognitivnega prevajanja v procesu prevoda prevedi prevodno zmožnost in metaforično enakovrednost prevajane metafore. Vendar pa je na takšen način vseeno spregledan pomemben odnos do kulturnih modelov. Tokratna raziskava vpeljuje Cienkijevo teorijo (1999), ki temelji na tem, da je odnos med konceptualno metaforo in kulturnim modelom primerljiv z odnosom med profilom in osnovo ter da so možnosti interpretacije in uporabe konceptualnih metafor odvisne od kulturnih modelov, in z njeno pomočjo kritično oceni hipotezo kognitivnega prevajanja. Ugotovitve raziskave kažejo, da so bili prevajalci povečini uspešni pri prevajanju metafor, katerih izvorna in prevajana različica imata skupni kulturni model. Na drugi strani so različni kulturni modeli vzrok za neuspešnost pri prevajanju metafor. Iz tega lahko sklepamo, da je lepljenje metafor

Acta Linguistica Asiatica, 7(2), 2017.

ISSN: 2232-3317, http://revije.ff.uni-lj.si/ala/

DOI: 10.4312/ala.7.2.19-36 
iz enega jezika $v$ drug jezik močno povezano $s$ kulturnim modelom izvornega in ciljnega jezika ter njunim odnosom, ter predlaga redefinicijo pogojev SMC in DMC.

Ključne besede: metafora; kulturni model; prevod; SMC; DMC; perzijščina; angleščina; kurdiščina

\section{Introduction}

There is a controversial triangular relation among metaphor, culture and translation in translation studies. Different explanations and various procedures are proposed for this phenomenon (e.g. Dagut, 1976; Newmark, 1988, 1995; Larson, 1998; van den Brock, 1981; Alvarez, 1993). It is assumed that the dilemma of the translatability of metaphor in target language is affected by cultural overlap and cultural relativism. Recently, by a cognitive study of metaphor and culture, cognitive approaches to translation have appeared (for further information see Tabakowska, 1993, 1997; Mandelblit, 1995; Al-zoubi et al., 2009). This new approach investigates metaphor translation at the conceptual level. So, the problem of translatability is projected from linguistic expressions to conceptual phase. Mandelblit (1995) describes this cognitive turn as 'not only a transfer from one language to another but also a transfer of one way of conceptualization to another' (Mandelblit, 1995, p. 456). He assumes that in the process of translating metaphor there may be two different conditions. If the mapping condition between source and target domains is the same for source and target languages, there will be similar mapping condition (SMC) resulting in the high possibility of reproducing the metaphor in the target language and achieving equivalency. But if the mapping condition between a source and a target domain is different for a source and a target language, there will be different mapping condition (DMC). Consequently, achieving equivalency will be more difficult and will require more time and efforts (Mandelblit, 1995, pp. 489-492). In other words, the more similarities the two cultures demonstrate, the more possible the SMC, and the other way around; the more the cultures are different, the more possible gets the DMC (Al-zoubi et al. 2009).

However, according to Cienki (1999) the conceptual metaphor is itself a nonautonomous, relational conceptual entity. Metaphor as a conceptual structure depends on cultural models. He explains this dependency as the relationship between a base (cultural model) and a profile (metaphor). Accordingly, cognitive translation hypothesis by Mandelblit (1995) should undergo another transformation, not only a transfer from linguistic expressions to conceptual structures, but also a transfer from a conceptual metaphor as a profile toward its relationship to cultural models as a base. The translator should therefore consider a triangular relation composed of metaphorical linguistic expressions, conceptual metaphor and cultural models. This paper aims to examine the problem by investigating the Kurdish and English 
translations of Omar Khayyam's poetry. The Kurdish translation is by A. Sharafkandi (2011) and the English translation is by Edward Fitzgerald (1942).

\section{Metaphor and cultural models}

Metaphor in cognitive linguistics is not a pure figuration or a decorative instrument for making a joyful response in the reader. It is beyond the classical and metaphysical distinction between logical, literal language and poetic, figurative language (Lakoff \& Johnson, 1980/2003; Lakoff, 2006). Metaphor emerges from a kind of human experience which is shaped by understanding and experiencing something by something else. So, human subject can think about a complicated and abstract concept such as "love" by another concept like "journey". According to this theory the concrete concept of a journey is the source domain and the abstract concept of love is the target domain. "Love is journey" as a metaphor is the product of mapping between a source domain (journey) and a target domain (love). Mapping is a set of conceptual correspondences between elements of source and target domains, and therefore the metaphor cannot be reduced to a linguistic expression, but is treated as a conceptual phenomenon (Lakoff \& Johnson, 1980/2003, p. 5; Lakoff, 2006, pp. 190-192; Kovecses, 2010 , p. 4). Metaphors in ordinary language and poetic language enjoy similar procedures. There isn't an unbridgeable differential gap between them, but poetic metaphors are deeply dependent on conventional metaphors. Poets make poetic metaphors by using conventional metaphors according to some procedures like extension, elaboration, questioning, and combining (Lakoff \& Turner, 1989, pp. 69-71; Kovecses, 2010, pp. 52-55). Poetic language is a kind of manipulation of the conventional metaphors.

Metaphor is a dependent entity which emerges from certain cultural models in a specific way. Before we delve into this topic, let's define what exactly a cultural model is. Idealized cognitive models are intersubjectively shared cultural schemas that function to interpret experience and guide action in a wide variety of domains including events, institution, physical and mental object' (Gibbs, 1999, p. 153). Human subjects comprehend and interpret the world by these models. For showing their mental nature they are called cognitive models and for emphasising their cultural identity they are labelled cultural models (Lakoff, 1987, p. 68; Lakoff \& Turner, 1989, pp. 65-67). Cultural models include metaphoric, metonymic, propositional, and image schematic models (Lakoff, 1987, p. 185, pp. 285-8; Evans \& Green, 2006, pp. 280-281).

Concerning the relationship between a metaphor and cultural models, Quinn (1987) defines cultural models as some pre-existing cultural propositions. They are literal and nonfigurative. Metaphors are reflections of these models and are shaped by them. Abstract concepts as cultural models are literal and metaphors fit to these preexistent cultural models. Lakoff \& Kovesces (1987) criticize Quinn and suggest the 
idea that cultural models (abstract concepts) are metaphorical. Kovecses (2005) then makes a compromise between his and Quinn's definition by stating that human beings take pre-existing metaphorical cultural models for granted and conceive them as literal, and only then produce and interpret new metaphors by using these pseudo-literal metaphorical cultural models (Kovecses, 2005, p. 224). Yu (1998) and Shanghai (2009) believe in a mutual and dialectical relationship between metaphor and cultural models. They believe that we produce and interpret metaphors according to cultural models but some cultural models can have a metaphorical nature. The theory of Lakoff and Kovecses (1987) doesn't explain the status of metaphor in relation to other nonmetaphorical models. Also it doesn't illustrate specifically the relationship between metaphors and cultural models. Quinn's theory (1987) can't explain the metaphorical nature of some metaphorical models, because it can't be ignored that many of the models are figurative (metaphorical, metonymical). Also, as Yu (1998) and Shanghai (2009) put it, there is a mutual relationship between metaphor and cultural models, but they don't expound the nature of this relation. In this paper we draw on the approach of Cienki (1999) which casts light on this relationship between all kinds of models and metaphors.

Cienki (1999) considers the relationship between cultural models and metaphors as the relationship between a base and a profile. For example circle is a base and radius is a profile. A ase is a whole cognitive structure and profile is the highlighted part of this whole (base). Interpretation and meaning of the profile is dependent on base. Base functions like a background and profile emerges from it. A base can have several profiles (Croft \& Cruse, 2004, p. 15). According to this theory, cultural models (propositional, metaphorical etc.) function as a base and metaphors as profiles. Producing and interpreting metaphors is dependent on cultural models. Because of the interpretative nature of this approach, and also because the approach may includes several different models, it represents a good framework for investigating the relationship between metaphors and different cultural models in translation. According to the theory of Cienki (1999), a metaphor is a relational conceptual entity and thus can not be considered as an autonomous conceptual system. This raises a question on how a metaphor as a concept dependent on cultural models can be fully reconstructed in translation. Metaphors are suggested to go not only beyond linguistic expressions but also beyond the mere conceptual structure, and scrutinize the relation of the metaphorical conceptual structure to cultural models, because metaphorical conceptual structure as profile is itself a relational and non-autonomous phenomenon and is highly dependent on cultural models. In interpreting a specific metaphor, a researcher should therefore consider a linguistics expression, conceptual structure of metaphor and the relation of conceptual metaphor as profile to cultural model as a base. 


\section{Metaphor, translatability and cultural impediments}

Metaphor in translation, according to cultural impediments, is a long open-ended story in the literature of translation. In classical approaches this phenomenon is scrutinized in linguistic level and not considered as a cognitive affair. Because they ignore the conceptual nature of a language, culture and equivalency, classical approaches can not go beyond the surface linguistic structures to evaluate the equivalency and cultural distances (for further information see Dagut, 1976; Newmark, 1988, 1995; Larson, 1998; van den Brock, 1981; Alvarez, 1993). Cognitive approaches to translation have revolutionized the concept of metaphor, culture and translation itself.

Tabakowska (1993, 1997) presents the idea of experiential equivalency. Experiential equivalency is based on conceptualization. Two texts are equivalent if they show similarity at the level of conceptualizations (Tabakowska, 1993, p. 128). Therefore the translator should go beyond the mere linguistic level and consider the phase of conceptualization and cognition. Culture as a determining factor in translation is also viewed as a conceptual entity. 'The lack of convergence between conceptual systems' of a source and a target language (or a non-convergent conceptual system) is the impediment for bridging the gap between these two different conceptual systems in translation (Tabakowska, 1993, p. 129). Cultural overlap or cultural similarity can be seen as the convergent conceptual systems of a source and target languages. Tabakowska (1993) presents a specific continuum to display the interaction of experience, culture and translatability: the idiosyncratic individual experience is positioned at the end of the scale of translatability (least translatable) while universal bodily experiences are situated at the other side of the scale (highly translatable). Culture specific experiences are at the middle of the scale (Tabakowska, 1993). Mandelblit (1995) also considers the dilemma of a metaphor translation beyond linguistic expressions and puts it in the conceptual structure. He defines translation as a kind of transformation from one specific kind of conceptual system (source) to another. So his cognitive translation hypothesis transfers the metaphor translation from 'a purely surface language problem to a cognition problem' (Mandelblit, 1995, p. 486). If the metaphor is not a language but a thought, then the 'process of metaphor translation would not only present a transfer from one language to another but also a transfer from one way of conceptualizing the world into another' (Mandelblit, 1995). If the source and target languages make use of different conventional correspondences to express the same domain of experience, the process of finding the target equivalent may require a conscious conceptual switch by translator. Accordingly, there are two different conditions in the process of translating a metaphor. The first one is similar the mapping condition (SMC). With the SMC mapping conditions between a source and a target domain are the same for both source and target language. This results in a high possibility of reproducing the metaphor in the target language and achieving equivalency. The second one is the different mapping condition (DMC). With the DMC 
mapping conditions between a source and a target domain are different for the source and the target language, and achieving equivalency is more difficult and needs more time and efforts in that situation (Mandelblit, 1995, pp. 489-492). In the DMS condition, achieving the right translation needs not only a shift between linguistic items, but also a shift between conceptual mappings (Mandelblit, p. 491). Al-zoubi et al. (2009) relate these two conditions to culture. If two cultures are close to each other, SMC is the dominant condition and if they are different, DMC is the dominant one. The cognitive theories scrutinize the metaphor equivalency at the conceptual level, and highlight the role of cultures as different conceptual systems. However, they consider conceptual metaphor despite of its vital relationship to cultural models. As mentioned before, a conceptual metaphor is a relational non-autonomous phenomenon that matches a profile in relationship to cultural models, which represent a base. There are threedimensional dependencies between linguistic expression, conceptual structure and the background base which is cultural model. The linguistic expression is tied to conceptual structures but the conceptual structures are interpreted according to cultural models. The aim of this study is to examine these metaphorical three dimensional dependencies of language, concept and cultural models in the process of metaphor translation. Cultural overlap and cultural differences will be judged according to these three dimensions. The DMC and SMC will thus be considered according to the dependency of conceptual system as profile on cultural model as base. Then the cognitive translation hypothesis will be revised according to these dimensions.

\section{Research data}

In this research, three of Khayyam's (2008) quatrains along with their translations by Fitzgerald (1942) and Abdorahman Sharafkandi (2011) were selected in order to study and analyze the relation between a metaphor and cultural models in the process of translation. The study employs purposive sampling to collect the required data. Firstly, quatrains containing the greatest number of metaphors were selected. Then among them, three quatrains which had been simultaneously translated by native English and a native Kurdish translator were chosen for further evaluation. Finally, three quatrains as well as their translations were selected and then according to the cognitive approach the relation between metaphor and cultural models in the source text and the two English and Kurdish translations were evaluated.

\section{Data Analysis}

In this section, three of Khayyam's (2008) quatrains along with their English and Kurdish translations were studied. 
(1) Text 1

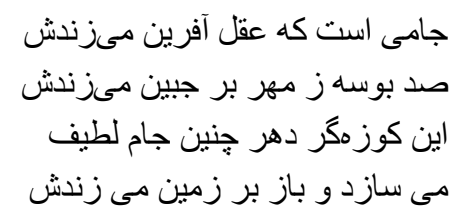

Reason creates a cup +

and then places kisses on its forehead //

this potter of dahr has made such a beautiful cup +

only to hit it to the ground again.

In this quatrain, Khayyam (2008) criticizes the ancient philosophical cosmology with his metaphorical language. The terms 'reason' and dahr (infinite time as the product of eternal rotation of the celestial spheres) are philosophical terms. Reason, dahr and the celestial spheres have a special relation to one another. In the ancient Persian cosmology God was the origin of being and 10 immaterial reasons initially emerge from Him. These ten reasons in turn create the celestial spheres and the celestial spheres create dahr (infinite time) with their eternal rotation. The tenth reason, as the last reason, bestows a special form and essence to creatures on Earth. Because of the movement of the celestial spheres and the resulting passage of time (dahr), creatures decomposed and disintegrated and lost their form and essence (Al-Fakhuri \& Al-Jar, 1988, pp. 417-420). In order to create his metaphors, Khayyam blends this ancient philosophical model with the pottery model. The first and second hemistiches state that reason like a potter creates a cup and then kisses the forehead of its creature like a lover. In this verse, reason, who bestows the form and essence to creatures, has been pictured as a potter.

1. REASON IS A POTTER.

2. CREATURE IS A CUP.

Afterwards, in the next verse, Khayyam (2008) depicts reason as a potter who makes cups and then breaks them. The interesting point is that in this verse the potter is related to the concept of dahr. The question on the relation between this potter and the dahr (eternal time) remains and will never be clearly answered unless we painstakingly investigate the interaction between the model of Persian pottery and the system of ancient Persian cosmology. We already explained the system of reasons and spheres. However, regarding the pottery model, it could be stated that a potter shapes clay material by means of a pottery machine. There is a circular plate on the pottery machine which the potter rotates with his feet and simultaneously shapes the clay into a cup with his hand. Therefore, it could be concluded that Khayyam (2008) has blended the ancient cosmology structure with the pottery structure in a very artistic way. Like a potter who shapes clay into a cup by rotating the pottery plate, reason, too, rotates the celestial spheres and gives shape and essence to creatures and then exposes them 
to death. The birth of a creature has been pictured as the making of a cup and his death as the breaking of the cup:

3. REASON IS A POTTER.

4. CELESTIAL SPHERE IS A POTTERY PLATE.

5. CREATURE IS A CUP.

6. BIRTH OF A CREATURE IS THE MAKING OF A CUP.

7. DEATH OF A CREATURE IS THE BREAKING OF A CUP.

Careful attention to the above metaphors reveals that the production and interpretation of these metaphors are completely dependent on the cultural model of pottery and the ancient Persian cosmological model. Without considering these two models we could not infer the above metaphors from the above quatrain. Now let us discuss the Kurdish translation of this quatrain.

(2) Text 2

læŝ nâsəku lâwčâki wæhâ hæn kořu kəč +

gol dəřkæ bærânbæri bekæsæ doř //

gærdun kæ bæ dæstânæ dæyânkâ, wæk ŝet +

tekyân hæĺæŝeletu dæyânkâtæwæ qoř

There are youths and delicate ones including girls and boys + unique diamonds compared to whom beautiful flowers are like thorns // gardun (destiny) who meticulously creates them, breaks them + and reduces them to earth (like pitcher).

In the above translation, the translator into Kurdish has obviously attempted to reconstruct the concepts of fatalism of Khayyam's (2008) quatrain, and did not use the term 'reason'in his translation. He has also dismissed the metaphors of pottery in the first and second hemistiches and has explicitly employed the concept of human and has substituted the delicate cup for delicate boys and girls. Of course, in this verse the translator has added a metaphor and compared humans to diamonds:

8. HUMAN IS A DIAMOND.

In the second verse, death and birth of a human have been conceptualized as the breaking and making of a pitcher. In this verse, instead of the philosophical concepts of Reason and celestial spheres, the translator has used 'gardoon'. The term gadroon in Kurdish language means destiny (Sharafkandi, 2002, p. 727). Therefore, destiny has been pictured as a potter who makes people like pitchers and then breaks them:

9. DESTINY IS A POTTER.

10. HUMAN IS A PITCHER.

11. DEATH IS THE BREAKING OF THE PITCHER.

12. BIRTH IS THE MAKING OF THE PITCHER. 
However, a close attention to the above quatrain reveals that the absence of the ancient Persian model of cosmology in the target text has led to the omission of the metaphors and their related meanings. Instead of the whole complex system of ancient cosmology, the translator has used the term 'destiny'. Because the pottery model was known in the Kurdish culture, the translator has been able to refer to the pottery concepts. In contrast, due to the translators' unfamiliarity with the ancient cosmological model and because this model was not known in the Kurdish culture, the metaphors relating to it have been omitted in the target language. This non-shared cultural model causes the lack of some metaphors in translation. Metaphors depending on non-shared cultural models are absent in the target language and are the main cause of lack of equivalence in translation whereas the metaphors dependent on the shared model of pottery have been recreated in the target texts.

(3) Text 3

Said one among them-surely not in vain +

my substance of the common earth was taken //

and to this figure moulded, to be broke +

or trampled back to shapeless earth again.

In Fitzgerald's (1942) translation, a pitcher narrates the vanity of existence. In this translation, the pitcher states that its existence could not be aimless and that there should be a reason to its being shaped in this way. Yet it has realized that there is no philosophical logic behind this issue and it has been made to be broken and lose its temporary shape. This narration, too, somehow shows the bewilderment in existence. The translation has attempted to picture existence as a kind of vain pottery. Accordingly, god or destiny has been conceptualized as an aimless potter. In this translation, too, the philosophical concepts of reason and dahr have been omitted. Destiny (or god) has been pictured as a potter who makes humans as pitchers and then smashes them. There is no trace of the ancient cosmological model and the intricacies of pottery in the English translation:

13. DESTINY (OR GOD) IS A POTTER.

14. MAN IS A PITCHER.

15. DEATH IS THE BREAKING OF A PITCHER.

16. BIRTH IS THE MAKING OF A PITCHER.

Since Persian and English share the pottery model, the metaphors relating to the pottery model have been translated. But because the ancient Persian cosmological model is non-convergent and non-shared, the translator has been unaware of its agency in the production and interpretation of metaphors. Therefore, the metaphors relating to it are absent in the target text and have not been transferred and this has led to the lack of equivalency. So here, too, the absence of a non-shared cultural model in the translated text has caused the related metaphors to be omitted. 
(4) Text 4

$$
\begin{aligned}
& \text { از روى حقيقتى نه از روى مجاز }
\end{aligned}
$$

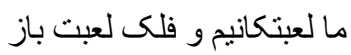

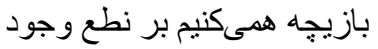

$$
\begin{aligned}
& \text { رفتيم به صندوق عدم يك يكى باز }
\end{aligned}
$$

In reality, not figuratively +

we humans are puppets and the celestial sphere a puppeteer //

we play on the rug of existence +

only to go, one by one, into the box of non-existence.

In this quatrain, Khayyam (2008) metaphorically describes human's life and destination. Despite the clarity of the metaphoric language in this quatrain, the poet states that these statements are genuine, not figurative. Despite his statement, there is no doubt about the presence of similes and allegories in this quatrain. Perhaps he has pronounced such a statement to emphasize his own words. To investigate this issue is beyond the scope of this study, and the study only discusses the metaphors in the quatrain. The quatrain's metaphors are dependent on various cultural models. Relying on three cultural models, the poet has created some metaphors in the above quatrain. It is impossible to understand these metaphors without having any presupposition about the intended models. The first model is the propositional model of a puppet show where some puppeteers play with dolls to entertain and amuse children (Dehkhoda, 1971, p. 1017). The second cultural model is the ancient astronomical model in the ancient Persian philosophy according to which nine circular celestial spheres revolve around the Earth and influence natural elements and rule over creatures and their fate (Al-Fakhuri \& Al-Jaz, 1988, pp. 505-507). These celestial spheres influence creatures on Earth by their rotation and determine their death, birth and fate. In fact, according to this philosophical model creatures lack free will, their fate being determined by the will of the celestial spheres. In this quatrain, based on the cultural and philosophical models, the poet conceptualized the world as a kind of a puppet show where the celestial spheres are the puppeteers and creatures are the puppets. Besides, in the third and fourth hemistiches, life of creatures has been pictured as a puppet show and the death pictured as the end of this show. This show is performed on the rug (nat') of existence and at the end of the show the puppets are returned into the puppeteer's box that conceptualizes the grave:

17. CELESTIAL SPHERES ARE PUPPETEERS.

18. CREATURES ARE PUPPETS.

19. LIFE IS A SHOW.

20. DEATH IS THE EAND OF THE SHOW.

21. EXISTENCE IS A RUG.

22. GRAVE IS A BOX. 
The above metaphors serve as profiles for the cultural model of a puppet show and the astronomical model. It is impossible to understand the above metaphors without being familiar with these models. However, the metaphorical interpretation of the quatrain does not end here. Nat' has yet another meaning. The term in ancient times, has also referred to specific leather. This is based on an ancient judicial-punitive model in Iran. According to this propositional model, death convicts were seated on a leather rug named nat' in the court of law to be decapitated by the executioner. In fact, the nat' was an integral part of this ceremony (Dehkhoda, 1971, p. 586). On the basis of this cultural model some other metaphors could be seen in the poem. Here, a creature is conceptualized as a death convict seated on the leather rug of existence, and the celestial spheres are executioners who decapitate the convict and put it back in the box (grave):

\section{CELESTIAL SPHERES ARE EXECUTIONERS.}

24. CREATURES ARE CONVICTS.

25. EXISTENCE IS A LEATHER RUG.

26. LIFE IS AN EXECUTION CEREMONY.

The above metaphors, too, are inferable only on the basis of the cultural model of the ancient judicial system and without that they are incomprehensible. The three models of old astronomy, puppet show, and the ancient judicial-punitive system therefore serve as the basis for metaphorical conceptualizations in this quatrain. Careful observation of the above metaphors reveals that the production and interpretation of such metaphors is fully dependent on cultural models. If the reader is not familiar with the three above-mentioned models, they can never understand the metaphors of the above quatrain. Now let us discuss the Kurdish translation of the quatrain.

(5) Text 5

gærdun wæku məndâ læbær bekâri + xstinyæ dærē wæk mətumur bo yâri // tâweki læbær dæstyâ deyno dæčin + dæxreynæwæ sænduqi næmân yækjâri

Like a carefree child, the gardoon (destiny) + drops humans like a child's beads // we move for a short while before him + and are returned to the box of inexistence.

The translator into Kurdish, too, uses a children's game (a game with beads) to convey the meanings of Khayyam's (2008) quatrain. Instead of celestial spheres, he uses the term gardoon which in Kurdish means destiny (Sharafkandi, 2002, p. 727). The term gardoon does not reflect the complex system of celestial sphere and hence the pictorial and complex metaphorical relation between the system of celestial spheres and 
puppet show could not be seen in this translation. In this translation destiny has been conceptualized as a child who is playing with humans as beads. The beads are returned to the box (grave) after the play:

27. DESTINY IS A CHILD.

28. HUMAN IS A BEAD.

29. LIFE IS A CHILD'S PLAY WITH BEADS.

30. DEATH IS THE END OF PLAY.

31. GRAVE IS A BOX.

Close examination of the metaphors reveal that the translator has replaced the puppet show with the child's play with beads. Because the puppet show model is known in the Kurdish culture, the translator has been aware about it and replaced it with bead play. However, he has failed to recreate the metaphors pertaining to the cultural models of old astronomy and the ancient judicial-punitive model in the target text. The reason for this non-equivalency could be the fact that the Persian model of astronomy and the ancient judicial system are unknown in the Kurdish culture. The absence of models specific to Persian culture in the target text has led to the absence of their dependent metaphors in the target text. In this case, the non-shared cultural models have caused non-equivalency; whereas the shared cultural model and its dependent metaphors have been replaced with similar metaphors. Now let us discuss the English translation.

(6) Text 6

But helpless pieces of the game + upon the chequer-board of night and days //

hither and thither moves and checks and lays + and one by one back in the closet lays./

Using the cultural model of backgammon in his translation, Fitzgerald attempts to reconstruct Khayyam's message about the meaning of life and existence. He conceptualized humans as checkers of a backgammon game being played by a person (he). The pronoun 'he' who is playing the game could be a metaphor for destiny. The white and black squares of the backgammon board serve as metaphors for day and night. Human life and death have been pictured as the duration of the game and its end. Also, in the fourth hemistich, the grave has been pictures as a box to which humans return at the end of the game (death).

32. DESTINY IS A PLAYER.

33. HUMAN IS A CHECKER.

34. LIFE IS A BACKGAMMON GAME.

35. DEATH IS THE END OF THE GAME.

36. DAY IS THE WHITE SQUARE.

37. NIGHT IS THE BLACK SQUARE. 
By carefully examining this translation it gets obvious that the translator has replaced the cultural model of a puppet show with the cultural model of a backgammon. The translator is aware about the agency of the puppet show model in the genesis of metaphors in the original text. Accordingly, he has replaced it with another model, that is the backgammon. However, the absence of the metaphors dependent on the cultural model of Old Persian astronomy and the judicial-punitive system in the poem is obvious. The reason for the absence of the metaphors dependent on these two models might be the fact that these two models are extremely dependent on Persian culture and the translator has failed to recognize the agency of these models in the development of a great proportion of these metaphors. Due to the dependency of the metaphors on these non-shared cultural models, the absence of these models in the translated text has led to the absence of their dependent metaphors.

Now let us discuss the next quatrain.

(7) Text 7

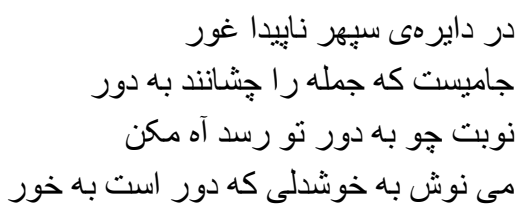

Within the circle of the fathomless celestial sphere + is a cup out of which everyone is made to drink by turns // when your turn comes up, do not say alas + but drink cheerfully for the rotation (of the celestial spheres) is right.

In this quatrain, relying on cultural models, Khayyam (2008) creates some metaphors referring to the world, humans, death and the passage of time. He first describes an infinite circle which is the circle of the celestial spheres, and then compares this circle to a tavern where the drunkards are sitting and the saqi (cupbearer) walks around the room and offers the wine in turn to each of them. Then in the next hemistiches he extends this concept. He advises people that if in the movement of the cup inside the celestial spheres the time arrived for someone to drink; he must drink it because it is the fate of humans. In fact, this quatrain is inspired by two ancient Persian models. The first cultural model is the ancient Persian astronomical model based on which the celestial sphere revolve around the Earth. These spheres are giant circles which rotate around themselves and influence the world of nature. The fate of all the creatures is determined by the rotation of the spheres. The rotation of celestial sphere creates time and the passing of time causes creatures mortality (Al-Fakhuri \& Al-Jaz, 1988, pp. 505507). However, this cultural model in the first hemistich is blended with the tavern model. According to the tavern model, the drunkards are sitting and the saqi (cupbearer) walks around the room and offers the wine in turn to each of them. In 
composing this quatrain, Khayyam (2008) employs these two cultural models and establishes mapping between them. Thus here the spheres are conceptualized as a tavern and creatures as the drunkards inside it. The significant point in this quatrain is that if the celestial spheres are a tavern, then who is the saqi (cupbearer) and why is his wine fatal? We could not find an answer to this question unless we refer to the cultural model of ancient astronomical model in Persia. As mentioned above, according to the ancient Persian model of astronomy, the rotation of celestial spheres cause time and time causes creatures mortality. Therefore, considering this it could be inferred that the saqi inside the tavern of the celestial spheres is time and the wine in his cup is death. The movement of time has been conceptualized as the movement of saqi. These metaphors could not be understood if one is unfamiliar with the ancient astronomical model.

38. THE CELESTIAL SPHERE IS TAVERN.

39. TIME IS SAQI (cupbearer).

40. DEATH IS THE WINE.

41. CREATURES ARE DRUNKARDS.

The metaphors of the above quatrain are based on two cultural models, i.e. the model of tavern and the ancient astronomical model. Now let us discuss the Kurdish and English renderings.

(8) Text 8

Gærdun mæyækæ-y mærgæ jihân meixânæ +

dærxwârdi dædâ hær kæse ley mivâna //

binoŝæ bæ ruy xoŝæwæ gær noræt hât +

jæžnekæ ŝæporâni lægæĺ yârânâ

The wine of gardun is death and the world is a tavern +

He offers this wine to his guests //

Now that it is your turn, drink the wine +

this is a celebration with companions and is accompanied by grief.

Instead of the concepts of celestial sphere, the Kurdish translator has used the concept of gadroon. The term gadroon in Kurdish language means destiny (Sharafkandi, 2002, p. 727). He has conceptualized destiny as saqi (cupbearer), the world as a tavern, and creatures as the drunkards. Destiny, like a saqi, offers the wine of death to his guests. In the third hemistich, addressing humans, the poem states that: now that it is your turn, drink this wine. In the end, in a paradoxical statement, the poem views the world as a blend of joy and grief. Having replaced the ancient model of astronomy by the concept of destiny, the translator could no longer use the picture of the celestial spheres as a tavern and time as the saqi. Due to the absence of the non-shared ancient Persian model of astronomy in the target text, a major part of its related metaphors have been omitted, too. However, because of the fact that the two source and target 
texts share the tavern model, the translator has been able to reconstruct the metaphors related to it:

42. WORLD IS TAVERN.

43. DESTINY IS A SAQI.

44. CREATURES ARE DRUNKARDS.

The Persian astronomical model is unknown in Kurdish culture; therefore its dependent metaphors are not transmitted into target txt. It is obvious from the above translation that the principle cause of lack of equivalency in the above translation is the absence of the non-shared ancient Persian model of astronomy and its dependent metaphors in the Kurdish translation. Now let us discuss the English translation of this quatrain.

\section{(9) Text 9}

While the rose blows along the river brink + with old Khayyam the ruby vintage drink // and when the angel with his darker draught + draws up to thee, take that and don't shrink. /

The English translator has attempted to depict death and the gloomy human destiny by recourse to some metaphors. Besides, the second hemistich contains an advice to join Khayyam in drinking wine. The only common point of these two hemistiches and Khayyam's (2008) quatrain is this very advice. However, Fitzgerald (1942) tries to reconstruct the sense of the metaphors of the original quatrain in the third and fourth hemistiches. In these two hemistiches, the translator speaks of a male angel (he) who approaches the drunkards with a cup of black wine which the drunkards must drink without sorrow. Fitzgerald (1942) employs a concept (the angel of death) taken from the cultural model of Christianity about death. In fact, he employs the concept of death angel by using the religious model of Christianity. He conceptualizes the death angel as a saqi who offers the black wine of death to creatures. The translator employs the cultural model of tavern and the model of Christianity regarding death to reconstruct the metaphor of Khayyam's (2008) quatrain. However, the main point in this translation is the substitution of the time metaphor as saqi in the original text by 'angel' as saqi in the target text. In fact, this substitution shows the agency of cultural models in the two texts. The metaphors of this translation are as follows.

45. THE DEATH ANGEL IS THE SAQI (cupbearer).

46. CREATURES ARE DRUNKARDS.

47. DEATH IS WINE.

48. BLACK IS BAD.

The metaphors of Khayyam's quatrain originate from the two cultural models of old astronomy and tavern whereas the metaphors of Fitzgerald's (1942) translation 
have originated from the cultural model of death in Christianity and tavern. Since the tavern model exists in the two languages, the metaphors pertaining to it have been translated. On the contrary, because the astronomical model is specific to Persian language and is unknown in the target culture, the metaphors pertaining to it have not been translated. In fact, the absence of the ancient astronomical model has caused its dependent metaphors to be omitted. In this translation, too, it could be seen that the principle cause of non-equivalency in the translation is the absence of non-shared cultural models in the target text and the subsequent omission of its dependent metaphors.

\section{Conclusion}

Investigation of the three quatrains along with their translations reveals that the nonshared cultural models are the main cause of non-equivalency in the translation. Since conceptual metaphors are a phenomenon dependent on cultural models, and their production and interpretation is impossible without referring to cultural models, the omission of an influential cultural model in the target text in translation leads to the omission or an erroneous interpretation of all the conceptual metaphors dependent on it in the target language. The translator's unawareness of the agency of the nonshared cultural models in the production and interpretation of the metaphors of the original text, or else their limitation for reconstructing them in the target text has led to the absence of most of the metaphors dependent on these models in the translation. On the contrary, the metaphors dependent on the shared cultural models have readily been recreated in the target text because the translator has been aware of the influence of these models on the conceptual metaphors of the target language and has interpreted and translated the metaphors accordingly. The findings of the present research reveal that in the first step, in order to understand and interpret the metaphors of the original text, the translator must consider the cultural models ruling over the original text. Afterwards, when translating a metaphor, they must recreate the relation between a metaphor and its specific cultural model in the target language. Translating a metaphor without considering its vital relation to the cultural model leads to non-equivalency in the target text. Therefore, in translating a metaphor, the translator must consider the verbal expression, the conceptual metaphor, and the relation between the conceptual metaphor and the cultural model. Accordingly, the concepts of Mandelblit's model could be rewritten in the following way. The similar mapping condition between the source and the target languages depends on shared cultural models and the different mapping condition depends on non-shared cultural models.

Similar mapping condition is the result of the similarity of the conceptual mappings of a metaphor in the source and target languages on condition that there is an identical 
or similar relation between these conceptual metaphors and the cultural models in these two languages. Different mapping conditions are the result of different conceptual mappings of a metaphor from the source into the target language, or of a different relation between conceptual metaphors and cultural models in the two languages. Therefore, a metaphor's experiential equivalency depends on a harmony among the three aspects of verbal expression, conceptual system, and cultural models in a source and a target language. Without considering this three-sided relation, experiential equivalency could not be achieved in the process of translation.

\section{References}

Al-Fakhuri, H., \& Al-Jar, K. (1988). History of Islamic Philosophy (translated into persian by Abdolmohammas Ayati). Tehran: Sazman Entesharat Enghelab Eslami.

Alvarez, A. (1993). On Translating Metaphor. Meta: Translation Journal , 479-490.

Al-Zouibi, M., Al-Ali, M., \& Al-Hasnawi, A. (2009). Cogno-CulturL Issues in Translating Metaphors. Perspective: Studies in Translatology , 230-239.

Cienki, A. (1999). Metaphor and Cultural models as Profile and Base. In R. W.Gibbs, \& G. Steen, Metaphor in Cognitive Linguistics (pp. 189-205). Amesterdam/Philadelphia: John Benjamin Publishing Company.

Croft, W., \& Cruse, D. (2004). Cognitive Linguistics. Cambridge: Cambridge University Press.

Dagut, M. (1976). Can Metaphor Be Translated. Babel , 21-33.

Dehkhoda, A. (1971). Dehkhoda Encyclopedia-Dictionary. Tehran: Tehran University Press.

Evans, V., \& Green, M. (2006). Cognitive Linguistics: An Introduction. Edinburg: Edinburg University Press.

Fitzgerald, E. (1942). The Rubaiyat of Omar Khayyam Rendered into English Quatrains. United States of America: Wlater J. Black, INC. Roslyn, N.Y.

George, L. (1987). Woman, Fire and Dangerous Things: What Categories Reveal about the Mind. Chicagi and London: University of Chicago press.

Gibbs, R. (1999). Taking Metaphor out of Our Heads and Putting it into the Cultural World. In R. Gibbs, \& G. Steen, Metaphor in Cognitive Linguistics (pp. 145-167). Amesterdam/ Philadelphia: John Benjamin Publishing Company.

Khayyam, O. (2008). Khayyam's Quatrains (Edited by Forouqi and Ghani). Tehran: Nahid.

Kovecses, Z. (2005). Metaphor in Culture, Universality and Variation. Cambridge and New York: Cambridge University Press.

Kovecses, Z. (2010). Metaphor: A Practical Introduction. Oxford and New York: Oxford University Press.

Lakoff, G. (2006). Conceptual Metaphor, the Contemporary Theory of Metaphor. In D. Geeraert, Cognitive Linguistics: Basic Readings (pp. 185-238). Berlin and New York: Mouton.

Lakoff, G., \& Johnson, M. (1980/2003). Metaphors We Live By. London: University of Chicago Press. 
Lakoff, G., \& Kovecses, Z. (1987). The Cognitive Model of Anger Inherent in American English. In N. Quinn, \& D. Holland, Cultural Models in Language and Thought (pp. 195-221). Cambridge and New York: Cambridge University Press.

Lakoff, G., \& Turner, M. (1989). More Than Cool Reason: A field Guide To poetic Metaphor. Chicgo and London: University of Chicago Press.

Larson, M. L. (1998). Meaning Based Translation: A Guide to Cross Language Equivalence. Lanham: University Press of America.

Mandelblit, N. (1995). The Cognitive View of Metaphor and Its Impliction for Translation Theory. Translationa and meaning , 482-495.

New Mark, P. (1995). A textbook of Translation. New York and London: Prentice Hall.

New Mark, P. (1988). Approaches to Translation. New York and London: Prentice Hall.

Quinn, N. (1987). Convergent Evidence for a Cultural Model of American Marriage. In N. Quinn, \& D. Holland, Cultural Models in Language and Thought (pp. 173-194). Cambridge and New York: Cambridge Univrsity Press.

Shanghai, W. Y. (2009). On the Relationship between Metaphor and Cultural Models, With Dta from Chinese and English Lnguages. Metaphorik , 115-134.

Sharafkandi, A. (2002). Hanbaneh Bourineh, the Kurdish-Persian Dictionary. Tehran: Soroush.

Sharafkandi, A. (2011). Translation of Khayyam's Quatrains into Kurdish (Edited by Ashti). Tehran: Koule Poshti.

Tabakowska, E. (1993). Cognitive Linguistica and Poetics of Translation. Tubingen: Gunter Narr Verlag.

Tabakowska, E. (1997). Translating a Poem from a Cognitive Linguistic Perspective. Target , 2540.

Van Den Broeck, R. (1981). The Limits of Translatability: Exemplified by Metaphor Translation. Poetics Today: Translation Theory and Intercultural Relations, 73-87.

$\mathrm{Yu}, \mathrm{N}$. (1998). The Contemporary Theory of Metaphor: A perspectivr from Chinese. Amesterdam/Philadelphia: John Benjamin Publishing Company. 